\title{
Assessing Students’ Learning Autonomy According to Seven Jumps Technique in Higher Education
}

\author{
Mukminan, Muhammad Nursa’ban', Suparmini \\ Geography Study Program, Faculty of Social Sciences, Yogyakarta State University \\ *Corresponding author: mnsaban@yahoo.com \\ Received May 01, 2013; Revised August 01, 2013; Accepted August 06, 2013
}

\begin{abstract}
The aim of this study was to investigate the direction of the effect seven jumps learning technique in order to understand the students' learning autonomy. This study was an explanation research applying causal assosiatif correlation. The participants were 60 students of geography study program who took subject geography learning plan in 2012. The data were collected using a questionnaire and analyzed using bivariat statistic. The main finding was that seven jumps technique increased students' learning autonomy with signifancy value $(p)=0.000$, where significancy level $(\alpha)=0.005$. Analysis on the all participant indicated that $p$ is less than $\alpha$. It could be concluded that there was a relationship between seven jumps learning techniques and student's learning autonomy. The results of statistical calculations using Spearman Rank correlation was obtained value of the correlation $(\rho)$ 0.511 , it mean that the relationship between learning techniques with independence included seven jumps in good categories.
\end{abstract}

Keywords: student, autonomy, seven jumps, learning

Cite This Article: Mukminan, Muhammad Nursa'ban, and Suparmini, “Assessing Students' Learning Autonomy According to Seven JumpsTechniqueinHigher Education.” American Journal of Educational Research 1, no. 7 (2013): 263-266. doi: 10.12691/education-1-7-8.

\section{Introduction}

The teaching and learning in Higher Education is demanded to develop student competency which is indicated by their behavior, attitudes, and knowledge. The development of teaching and learning process within this level is little bit different from that of within the basic and secondary level. The learning autonomy of higher education student is the root for the learning process of an adult learner (andragogy). According to another definition, learning autonomy is a process of directing the learners' self-motivation to develop the potential in learning of an object without any pressure or external influences [1]. He adds that autonomy is more directed to the development of learning strategies. Moreover, student is an adult human being who is expected to position him/herself as an aotunomous learners in which they are able to decide the learning strategies and relevant resources to optimize their leaning capability [2]. In line with those two views, there are statement that students have some responsibility for managing their own learning and are traditionally responsible for the work they put into completion of assignments and revision for exams [3].

Some views of the educational experts state that last decades, the main goal of higher education has shifted from making students acquainted with a certain domain, to raising reflective and autonomous learners [4]. Therefore, students are now expected to develop autonomous and in depth learning competencies in order to adapt to the lifelong learning and to face unexpected new situations [5]. The characteristics of the autonomous learners can be viewed from how they start learning, manage the time in learning, perform a learning using strategies and techniques based on their ability as well as recognize their weaknesses.

In reference to some views above and in line with the idea, the characteristics of student's learning autonomy are: 1) able to think critically, creatively, and innovatively, 2) not easily affected by other ideas, 3) not run away from the problems, 4) solve the problems by performing deep thinking. 5) solve the problems without any help from others, 6) not humiliate him/herself if different from others, 7) work hard and discipline, and 8) responsibe for his/her action [6]. According to the writer, the students should be taught using appropriate methods in order to be autonomous learners therefore from the beginning of giving assignment, the students are supposed to perform self- motivation and initiative to arrange their own way of learning based on the appropriate methodology and undergo some learning steps as it is supposed to be.

In reference to the writer's note during teaching in higher education, there is a problem related to the student's learning autonomy. The students find difficulty to formulate and express their ideas and are not accustomed to compete with their friends in expressing opinions. The lecturers' explanation becomes the central point to rely on. Moreover, some students of the writers also reveal that sometimes the students can not catch the core of the problems and the formulation of teaching objectives, for example, when discusing a case, the result 
of the discussion is far from what is expected. Another case is when the students are asked by the researchers directly, eight among ten students state that they are lazy to look for learning resources and prefer to be given teaching materials directly from the lecturers.

The problems which are revealed above inspire the writers to find a solution by adopting the student's centered teaching model and competence-oriented teaching model, that is, applying Problem Based Learning (PBL) which is developed by McMaster University in Hamilton, Ontario, Canada in the late of 1960s by Howard Barrows and his colleagues. Problem-based learning model is able to improve the students' active participation and student's learning outcomes [7]. Furthermore, Problem Based Learning (PBL) isa student centered learning and its life rely on the tutorial process [8]. Added to this states that the main principles of tutorial is "student's autonomy" [9]. One of the teaching techniques in the tutorial methodology developed by Schmidt danBouhuijs [10] is employing seven steps (seven jumps) in that it is important to give big roles and responsibility to learners. Those steps are; 1 ) clarifying the terminology and concept which are not understood, 2) defining a problem; 3) analysing the problems and offering temporary explanation, 4) inventering various explanations needed, 5) formulating the teaching objectives, 6) collecting information through autonomus learning, 7) syntesizing, testing and evaluating new information related to the problems and reflecting the learning outcomes.

\section{Formulation of Problem}

In reference to the background of the problems, the research problems are formulated as follows; Is there a positive and significant effect of the use of seven jumps technique to learning autonomy in Geography Education Department?.This study is an explanation research applying causal assosiatif correlation. The independent variable is implementing teaching using seven jumps techniques through some steps proposed by Schmidt danBouhuijs. Meanwhile the dependent variable is the student's learning autonomy to responsible for the tasks at hand autonomously and is not relying on others. The learning autonomy is shown by 8 indicators as mentioned by ChabibThoha and is developed into 14 assesment aspects. To measure the data, the researcher used a question are with ordinal number rating scale which are divided into four categories namely, excellent ( $>45.5)$, good (35-45.5), average (24.5-34.9), and fair (<24.5).

The research was conducted from May to June 2012. The participants of the research were 60 students of Geography education department who took Geography lesson planning course in 2012. The data were collected using a questionaire and analyzed using bivariat statistic. The data were further analyzed using regression parameter statistic.

The question are consists of four answers (rating scales) below:

Sl: always, if the statement in the questionare suits with the real condition and is always done

Sr: often, if the statement in the questionare suits with the real condition and is sometimes done

$\mathrm{Jr}$ : seldom, if the statement in the questionare is hardly ever done

$\mathrm{TP}$ : never, if the statement in the questionare is never done.

\section{Discussion}

The subject of the research is 60 students of NonReguler programs who take Geography Lesson Planning course within the even semester in 2012. Based on the observation, the students' autonomy in this class is not optimal yet. This can be overcome by implementing Seven Jumps techniques in teaching.

SevenJumps techniques are applied twice within four meetings. Each meeting last for 150 minutes or equals to 3 course credit. During the application of the techniques, two basic competencies are formulated namely, "analyzing the formulation of lesson plan" with main materials "teaching analysis" and "indetifying the structure of basic competence attitudes" with main teaching materials" the structure of basic competence attitudes”. Each main material is finished within 2 meetings. The researcher utilized peer assesment question are to measure the learning autonomy of the research subjects.

The description of the average percentage of the students who involve in each of the autonomy assesment is presented in Table 1.

Table 1. The average of the student's autonomy percentage in Geography Education Department

\begin{tabular}{|c|c|c|c|}
\hline Indicators & Assesment aspects & $\mathrm{f}$ & $\%$ \\
\hline \multirow{4}{*}{$\begin{array}{l}\text { Able to think critically, creatively and } \\
\text { innovatively }\end{array}$} & $\begin{array}{l}\text { Think critically by confirming whether or not the information is valid when getting } \\
\text { information from friends }\end{array}$ & 33 & 55.00 \\
\hline & Able to give an alternative solution for solving a problem during a group discussion. & 34 & 56.67 \\
\hline & Able to express a new idea or opinion during a group discussion. & 29 & 48.33 \\
\hline & Stand on the opinion which they think is right. & 38 & 63.33 \\
\hline Not easily affected by other opinions & Not easily affected by other opinions or information which is not valid. & 36 & 60.00 \\
\hline Not run away from the problems & $\begin{array}{l}\text { If there is a friend or tutor asking for opinion, give answer based on the knowledge } \\
\text { and don't run away from the problems. }\end{array}$ & 42 & 70.00 \\
\hline Solve the problems by perforı & Think deeply to find the best solution to solve the problems. & 35 & 58.33 \\
\hline \multirow{2}{*}{ Solve the problems without any help from others } & Solve the problems without asking for help to others during the discus & 35 & 58.33 \\
\hline & Complete the tasks without relying on others. & 37 & 61.67 \\
\hline \multirow{2}{*}{$\begin{array}{c}\text { Not humiliate him/herself if different from } \\
\text { others }\end{array}$} & Not ashamed if his/her opinion is different from others. & 41 & 68.33 \\
\hline & Keep expressing the idea although it differs form others. & 39 & 65.00 \\
\hline Work hard and discipline & Complete the task by seriously looking for literature review. & 32 & 53.33 \\
\hline \multirow[b]{2}{*}{ Responsibe for his/her action. } & complete the task on time & 46 & 76.67 \\
\hline & $\begin{array}{l}\text { Responsible for all ideas expressed during the discussion because the idea is } \\
\text { supported by valid resources. }\end{array}$ & 46 & 76.67 \\
\hline Average & & 37 & 62,26 \\
\hline
\end{tabular}


Learning autonomy is learning activity which is enhanced by self-willingness, self-choice, and selfresponsibility without any help from others as well as able to responsible for the action. Autonomous students are those who are capable of completing the learning tasks without relying on others. The research findings show that the student's autonomy in Geography lesson planning course using SevenJump techniques belong to the category of "good" in that the average of each action is 37 respondents $(62,26 \%)$. In reference to the analysis of the measured indicators, it shows that the top three respondents, if they are asked by their friends or tutors, answer based on their knowledge, do not run away from the problems, finish the tasks on time, responsible to the ideas they expressed during the discussion because their ideas are supported by valid resources. Whereas, the indicator of student's learning autonomy which needs to be improved is the ability to express a new idea or opinion during the discussion, this still belongs to the category of "fair". The results in Table 1 generally agree with the experts state that learning isa change in behavior, either observed or not observed directly and occurs in a person because of the experience. Another meaning that learning isa process of individual effort made to obtain a change in behavior is relatively settled, both observable and unobservable directly incurred as a result of training or experience in the interaction with the environment [11].

Meanwhile, the description about the influence of teaching which employs Seven Jumps techniques on the learning autonomy of Geography Education department students in Geography lesson planning course is presented in Table 2 below.

Table 2.Cross table about the influence of teaching which employs seven jumps techniques on the students' learning autonomy



The data in Table 2 shows that more than a half of the respondents (51.67\%) state that the teaching which applys Seven Jumps techniques belong to the category of "good" and the student's autonomy of more than half of the respondents belong to the category "good" as well (63.33\%). The lowest level of students' autonomy or within the "fair" level reach $6.67 \%$. Whereas the respondents who state that the teaching using seven jumps techniques showing the category of "fair" reach $10 \%$.

The stastistic calculation which use Spearman Rank correlation for the teaching which employs Seven Jumps techniques with autonomous learning in Table 1 shows that the value of $\rho$ count $(\alpha)$ is 0.511 with significance level (p) 0.000. If $\mathrm{p}$ value is greater than $\alpha$, there will be no correlation between both variables. On the contrary, if p value is less than $\alpha$, there will be a correlation between two variables. The findings of the research reveal that $p$ value is less than $\alpha(0.000<0.05)$. With regard to this, it can be concluded that there is a correlation between Seven Jumps techniques and student's learning autonomy. This is based on the correlation coefficient value 0.511 which shows that the correlation between teaching with seven jumps techniques and student's autonomy belong to the category of "good".

The students's autonomy in Geography Education Department as in Table 1 has shown that seven jumps techniques can be used as a basis to perform autonomous learning activities although some aspects of assessment still belong to the "fair" category. This can be concluded that seven jumps technique is a learning tool which helps develop the student's learning autonomy, discipline, selfinitiative by minimizing the influence from their lecturers.

In the teaching which utilizes Seven Jumps techniques, the lecturers do not play role as an expert anymore (teacher-centered). The role of the lecturers has shifted into a "facilitator" or "tutor"; moreover the students do not role as "anakdidik” but also “pesertadidik”. Both students and tutors are the subject of teaching while the teaching scenario which is designed in order that the students achieve the goals is the object of teaching. In line that state that the objectives of applying problem-based learning, tutorial, and seven jumps techniques are improving the student's ability to be critical and helping them to be active and autonomous learners (self directed learners [12]).

\section{Conclusion}

In reference to the discussion and research objectives, itcanbeconcludedthatthereis a positive and significant influence of the use of Seven Jumps techniques on the students' participation and leaning autonomy in Geography lesson planning course at Geography Education Department Faculty of Social Sciences YSU 2012. This means that the teaching and learning process which apply seven jumps techniques can be used as one of the ways to improve the student's learning autonomy as adult learners (andragogy). It is expected that this research can be used by the educators within the level of adragogy like lecturers to meet the teaching goals. Moreover, the higher education may give a follow up by developing teaching models and methodsin line with the learners needs which are getting more and more varied.

\section{References}

[1] Surya, Hendra (2003). Kita mengajakanakbelajardanberprestasi. Jakarta: elex media computindo.

[2] Hidayati, Kana danEndang Lies (2010). Pengembangan Instrumen Kemandirian Belajar Mahasiswa. Yogyakarta State University: Faculty of Mathematic and Sciences.

[3] Stephenson, J, (1998). Supporting Student Autonomy in Learning, in Capability and Quality in Higher Education, Kogan page, London.

[4] De Clercq,Mikae“ l, Benoit Galand, MarianeFrenay. (2013) Chicken or the egg: Longitudinal analysis of the causal dilemma 
between goal orientation, self-regulation and cognitive processing strategies in higher education. Studies in Educational Evaluation. Page 4-13.

[5] Poldner, E., Simons, P. R. J., Wijngaards, G., \& van der Schaaf, M. F. (2012). Quantitative content analysis procedures to analyse students' reflective essays: A methodological review of psychometric and edumetric aspects. Educational Research Review, 7(1) http://dx.doi.org/10.1016/j.edurev.2011.11.002.

[6] Thoha, Chabib. (1996). KapitaSelektaPendidikan Islam, Yogyakarta : PustakaPelajar.

[7] Suci, Ni Made (2008). Penerapan Model Problem Based Learning UntukMeningkatkanPartisipasiBelajardanHasilBelajarTeoriAkunt ansiMahasiswaJurusanEkonomiUndiksha.

Journal of PenelitiandanPengembanganPendidikan. Volume 1, Number 1, April, page 74-86.
[8] HarsonodanDwiyanto, Djoko. (2005). Pembelajaranberpusat Mahasiswa. Yogyakarta: Aditya Media Yogyakarta and GadjahMada University. page 36.

[9] Widuroyekti, Barokah (2006). Pendekatan Belaja rAktifdan Peningkatan Partisipasi Mahasiswadalam Proses Tutorial TatapMuka. Journal of Education, Voume. 7, Number 1, Maret 2006, 55-65.

[10] Jos Moust, P. Bouhuijs, Hans Schmidt. (2007). Introduction to Problem-Based Learning. Taylor \& Francis.

[11] Dimyati dan Mudjiono. (2002). BelajardanPembelajaran. Jakarta: Rineka Cipta.

[12] Kurniawan, Felicia; Suryawinata, K. (2003) Pendapat Mahasiswatentangpenerapanmetode Problem Based Learning di FakultasKedokteran UNIKA Atmajaya. Medical Magazine of AtmajayaVol 2. Number 2, May2003. 